\title{
JOURNAL.RU
}

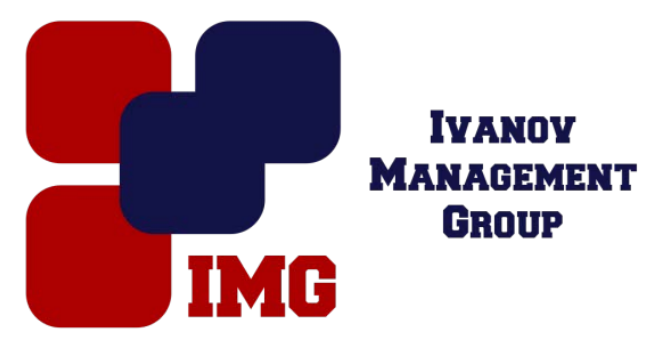

Гришечкина Г.Ю., Горынина Ю.А. Орловский государственный университет имени И.С. Тургенева Орел, Россия

doi: 10.18411/lj-30-04-2017-2-06

idsp 000001:lj-30-04-2017-2-06

\section{Исследования проблемы девиантного поведения несовершеннолетних в Великобритании и США}

\section{Аннотация}

В статье осуществлён анализ некоторых научных исследований проблемы девиантного поведения несовершеннолетних в США и Великобритании. Рассматривается проблема и сущность девиантного поведения несовершеннолетних.

Ключевые слова: девиантное поведение, молодёжь, Великобритания, США, научные исследования.

\section{Abstract}

The article presents the analysis of some scientific researches of problems of deviant behavior of juveniles in the United States and Great Britain. the problem and the essence of deviant behavior of juveniles are discussed.

Key words: deviant behavior, youth, United Kingdom, United States, scientific research.

Проблемы правонарушений несовершеннолетних всегда вызывали исключительный интерес общественности и были под пристальным вниманием психологов, педагогов и самого государства. Сегодня мы можем видеть духовную пустоту и моральное опустошение, безысходность у многих членов социума, следует отметить формирование повышенной тревожности, жесткости отношений у подростков и молодежи. С этим посылом связан и рост преступности в этой среде, который всегда связан с неблагополучным состоянием общества, но даже в 
развитых зарубежных странах, таких как Соединенные Штаты Америки и Великобритания, наблюдаются схожие процессы. Большинство подростков и молодежи США и Великобритании выражают себя так же, как и их сверстники в России: подражают, отдают дань моде, представленной в эфире телевидения, как в стиле одежды, так и в манерах поведения, как в яркости красок, так и не забывают употребление и алкоголя и наркотиков, но происходит и совершение преступлений.

Рассмотрим девиантную типологию популярную как в Англии так и в Соединенных Штатах Америки. Представляем самые популярные классификации:

- Классификация девиантов по Бёрт Сирил Людовику представляется тремя основными разделами на базе наследственных и биологических характеристик: отсталые, дефектные «defective child»,- врожденное слабоумие «intellectual faculties oligophrenia», «the dull»,- отсутствие заботы о детях, запущенные дети «the neglect of one children» «the neglected».

- Классификация девиантов по Хьюитт и Дженкинсу представлена тремя социальными группами:

- дети с симптомами нервных заболеваний, дети невротики, у которых проявляется повышенная возбудимость, плаксивость, раздражительность;

- ассоциальный тип личности, не соблюдающий правила жизни общества, у них нет угрызения совести, нет стыда за свои поступки, даже если они совершены против правопорядка, проявляют импульсивность, эгоизм;

- псевдосоциальные мотивы при правонарушениях, которые совершены ради норм, интересов и ценностей отдельных социальных групп, которые оказывают влияние на этих правонарушителей.

- Альберт Бандура классифицирует девиантов по трем группам:

- несоциализированное агрессивное поведение, представляют собой патологические формы девиантного поведения; они могут уйти из школы, уйти из дома и т.д. (unsocialized, aggresive type);

- социализированные группы правонарушителей, объединенные своими, действующими в данной группе условиями(socialized, normal, peer-oriented delinquent); 
- Ситуативные правонарушители совершают правонарушения лишь в условия $\quad$ конкретной жизненной ситуации (situational delinquents).

Согласно статистике девиантного поведения подростков, проведенной и в США и Англии, наличествуют и криминогенные (количественные) и социальные и педагогические (качественные) признаки, которые указывают на пол подростков, их образовательный уровень, положение в семье и т.д..

Количественные признаки необходимы для того , чтобы понять девиантное поведение подроствка, качественные признаки очень важны для профилактической работы и реабилитации несовершеннолетних девиантов

В отдельные периоды уровень преступности среди несовершеннолетних временно снижается, однако общая тенденция к росту девиаций среди несовершеннолетних является достаточно устойчивой.

Как свидетельствуют результаты исследований, в последние годы существенно снизился возраст детей, совершающих правонарушения, или же находящихся в ситуации риска. Так, количество дошкольников, которые находились в неблагоприятных для их нормального развития семейных условиях и дела которых были переданы для рассмотрения Комиссии, составляло в 1996 году 2995 детей (11\%), а в 2010 году - 11975 (22\%). Бесспорно, дети этого возраста еще не способны совершить правонарушение, но уже в возрасте 7-8 лет они могут стать на путь совершения криминальных действий. Следовательно, условия воспитания детей в семье имеют важное значение. Именно здесь начинают проявляться первые симптомы отклонений в нравственном развитии и поведении личности [Millar,2012 ].

Тот факт, что пребывание ребенка в неблагоприятных семейных условиях влияет на формирование девиантного образа поведения подтверждается цифрами, которые свидетельствуют, что чаще всего в Комиссию по делам несовершеннолетних обращаются в отношении детей из неблагополучных семей.

Возрастной профиль несовершеннолетних девиантов, как свидетельствуют результаты исследований, остается относительно постоянным в течение последних лет (с наибольшим количеством правонарушений в 15-летнем возрасте).

Значительный рост преступности и других девиантных проявлений среди несовершеннолетних заставляют ученых активизировать исследования проблемы девиантного поведения и ее профилактики. Однако, анализ научных исследований зарубежных ученых свидетельствует об определенных трудностях, с которыми 
сталкиваются исследователи. В частности, даже сегодня среди ученых все еще нет единства в толковании термина «девиантность) (чаще употребляется «делинквентнисть») несовершеннолетних [ Asquith,2005:41].

На сегодняшний день в зарубежной научной литературе не существует четкого определения терминов «juvenile» (несовершеннолетний) и «delin-quency» (делинкветнисть, правонарушения, преступность). В странах Западной Европы возраст головной ответственности и наказания существенно отличается. Например, в Шотландии, где существует уникальная система судов по делам несовершеннолетних, возраст уголовной ответственности предусмотрен в 8 лет. В Англии и Уэльсе уголовная ответственность начинается с 10-ти лет.

Ученый Ф. Данкел (F. Dunkel), который осуществил анализ различий в системах уголовно правовых мер в отношении несовершеннолетних в Европе, отметил, что развитие мероприятий в сфере профилактики правонарушений среди несовершеннолетних в разных отражает очень разное понимание самого термина «несовершеннолетний» [Dunkel,2001:14].

В английском языке понятия "delinquency", "delinquent" заимствованы из латинского языка (лат. delinquentia - проступок, прегрешение; delinquo, de-lictum совершить проступок, допустить погрешность, провиниться) [Словарь иностранных слов, 1988:152]. В современном английском языке понятие "delinquency" (по Оксфордскому словарю) означает: пренебрежение обязанностями; виновность; преступное бездействие; проступок; "delinquent": 1. не выполняющий обязанности, виновный; 2. правонарушитель, преступник [Тhе Concise Oxford Dictionary of Current English, 1989:252]; (по словарю Хорнби) "delinquency": 1. пренебрежение обязанностями, невыполнение обязательств; 2. проступок; ошибка; вина; "delinquent" - пренебрегающий обязанностями или совершающий проступок [Нornby A. S.,1985:306]; американский словарь Вебстера определяет делинквентность как "нарушение, намеренное или не преднамеренное, общественных норм или юридических законов" [Webster's Seventh New Collegiate Dictionary 1991: 105]

Возможны и другие варианты применения этих понятий-деликвентность и делеквент, которыми можно представить подростков с отклонениями в социальном поведении: «problem children» - трудно воспитуемые дети, «misbehaving children» - дети с плохой приспособляемостью, «no adapten children” - дети с плохой адаптацией, «emotionally disturbed children» - дети с неуравновешенной эмоциональностью, «socially maladjusted» - дети непрспособленные к социальным условиям и ...Можно отметить, что конкретной 
точной классификации таких определений нет и авторы, каждый в своем штате, по-своему определяет содержание в эти понятия.

Следовательно, главное понятие этого явления - нарушение принятых в обществе социальных норм, проступок, другое же понятие- преступление, преступность применяется в ходу намного реже и согласно этому синониму отражает небольшую степень серьезности преступления. Отметим, что в английском языке понятие преступление, преступность отмечаются словом «crime», у термина же деликвентность (delinquency) получается значительное количество самых различных толкований. Определяющие его положения:

- неисполнение социальных обязанностей, нарушения норм поведения, правонарушения;

- само делинквентное поведение;

- совершение проступка, ошибка, провинность;

- сам делинквент обозначается словами правонарушитель, даже преступник или виноватый.

Другая трудность заключается в том, что статистика предоставляет информацию только о правонарушениях, которые были сообщены в Комиссию по делам несовершеннолетних и зарегистрированы в полиции. Опять же, из-за различных классификаций возраста, разную природу систем правосудия и различные подходы к решению проблем правонарушений, возникают некоторые сомнения в надежности информации.

Анализ работ современных британских ученых свидетельствует о значительном разнообразии взглядов на природу девиантного поведения. Причины девиаций среди несовершеннолетних ученые объясняют действием разных факторов, среди которых некоторые являются действительно важными, другие же, по моему мнению, не слишком весомые.

1. Биологические факторы неблагоприятны физиологические или анатомические особенности организма ребенка, затрудняющих его социальную адаптацию.

* генетические, которые передаются по наследству (нарушения умственного развития, дефекты слуха и зрения)

* психофизиологические, связанные с влиянием на организм человека психофизиологических нагрузок, конфликтных ситуаций (развитие аллергических, токсических заболеваний); 
* физиологические, вызывают негативное отношение со стороны окружающих (дефекты речи, внешняя непривлекательность)

2. Психологические факторы обычно состоят в наличии у подростка либо психопатологии (выраженной психопатии), либо акцентуации отдельных характерологических черт, что приводит к общему дисбалансу личности и к повышенной уязвимости в отношении разнообразных психологических воздействий.

3. Социально-педагогические факторы имеют особенности влияния семейной системы на психическое развитие подростка («неблагополучные» семьи, дисгармоничные стили семейного взаимодействия), на трудности, возникающие в процессе школьного приводит к стойкой школьной неуспешности, разрыву связей со школой, что ведет в свою очередь к несформированности в старшем подростковом возрасте не только познавательных мотивов, но и школьных навыков, а также разнообразных интересов.

4. Социально-экономические факторы обычно имеют в виду социальное неравенство, расслоение общества, ограничение способов получения достойного заработка и социальную напряженность.

5. Морально-этические факторы касаются проблемы разрушения общественных ценностей, идеалов в сочетании с толерантным отношением и даже с равнодушием к проявлениям девиантного поведения со стороны, в том числе подростков.

Таким образом, подросткам с девиантным поведением присущи определенные психические состояния, качества личности и даже ценности, типичные для представителей определенного сообщества, кроме того, у них существуют определенные обычаи, традиции, речевая культура, которые можно рассматривать в качестве специфических регуляторов социального поведения.

Недостаточно изучен сегодня в зарубежной научной литературе вопрос девиантных проявлений среди девушек, хотя в последнее время в Великобритании научные исследования в этом направлении несколько активизировались [Browne А.,2006]. Это связано с существенным увеличением правонарушений и преступлений, совершенных девушками и женщинами. Например, в Шотландии среди всех несовершеннолетних, совершивших противоправные действия, более $40 \%$ девушек. Правда, для девушек и молодых женщин более характерны правонарушения, чем преступления. Девушки и женщины чаще получают формальные предупреждения, предостережения, их реже, чем мужчин, осуждают.

Исследователи подчеркивают, что причины, обусловливающие 
формирование девиантного образа поведения девушек и юношей, почти аналогичны, однако они требуют дальнейшего изучения и анализа. Особенно часто в случае девиантного поведения девушек доминирующим фактором выступает насилие (в том числе и сексуальное), которому подвергалась девушка, возможно, даже в детстве [Browne A.,2006].

Достаточно поверхностно исследованы вопросы девиантных проявлений среди несовершеннолетних и молодежи - представителей этнических меньшинств, хотя потребность в этом есть, поскольку количество правонарушений среди этой категории населения Великобритании в течение последних десятилетий ощутимо возросло [Ahmed S,2008], а поток мигрантов в Западную Европу постоянно увеличивается.

Значительные дискуссии происходят сегодня среди ученых по поводу применения уголовных наказаний в отношении несовершеннолетних. Значительная часть ученых отстаивает положение о том, что лишение свободы несовершеннолетних негативно сказывается на рецидивизме, и считая уголовное преследование «контрпродуктивным» [Harris R., 2003].

Сегодня большинством ученых признано, что проблемы молодежной преступности и антисоциального поведения не могут быть решены средствами уголовного правосудия. Исследования, проведенные в Великобритании, как и во многих других странах мира, свидетельствуют, что возможности системы уголовного правосудия (арест, возбуждение дела, осуждение, наказание) не являются эффективными средствами контроля преступности. Очевидна необходимость сотрудничества уголовного правосудия с другими институтами влияния на несовершеннолетних, что отражено в политике правительства Великобритании.

Региональные стратегии, которые должны решать проблемы преступности среди молодежи, действуют, как правило, в рамках государственной политики, определяются правительством. Правительство может влиять на уровень преступности, непосредственно поощряя превентивную работу полиции и других служб в сфере уголовного правосудия. Правительство может также влиять на уровень преступности опосредованно, через социальную политику, например, в сфере защиты семьи, образовательную, жилищную политику, политику занятости. Социальная политика способна усилить или ослабить возможности семьи и общественных учреждений в социализации и супервизии молодежи. Она может помочь или помешать в сложном переходе от детства к юности и от юности к зрелости. Таким образом, правильная или неправильная социальная политика 
оказывает положительное или отрицательное влияние на тех, кто потенциально может совершить проступок [Wallerstain J.,2008].

Таким образом, анализ научной литературы подтверждает, что в Великобритании активно осуществляются исследования различных аспектов девиантного поведения среди несовершеннолетних и молодёжи. Можно с уверенностью констатировать, что определяющим фактором появления дивиантного поведения подростков являются семейные отношения, что главное в семье любовь и бережное отношение к подросткам и только семейное воздействие может оказать существенное влияние на подростка. Общественные организации могут оказать воздействие на семью и через нее на подростка

\section{Литература}

1. Asquith S. Children, Crime and Society / S.Asquith // M.Hill, J.Aldgate (eds) Child Welfare Services. - London: Jessica Kingsley Publishers, 2005. - 200 p.

2. Dunkel F. Legal differences in juvenile criminology in Europe / F.Dunkel // T.Booth (ed). Juvenile Justice in the New Europe. - Sheffield: Social Services Monographs, 2001. - 201 p.

3. Словарь иностранных слов. - 15-е изд., испр. - М., 1988.

4. The Concise Oxford Dictionary of Current English, ed. by H. W. Fowler \& F. G. Fowler. London, 1989. 